\title{
Penerapan Model Inkuiri Sosial terhadap Kemampuan Berpikir Kritis Mata Pelajaran IPS di Sekolah Dasar
}

\author{
Dini Widya Astuti \\ Pendidikan Guru Sekolah Dasar, Universitas Sultan Ageng Tirtayasa, Indonesia \\ diniwidya26@gmail.com
}

\begin{abstract}
Abstrak
Penelitian ini bertujuan untuk mengetahui adakah perbedaan kemampuan berpikir kritis peserta didik dengan penerapan model Inkuiri sosial pada mata pelajaran IPS Kelas IV SD Negeri Pakulonan 01 Kota Tangerang Selatan. Metode Penelitian yang digunakan adalah kuasi eksperimen, dengan desain penelitian yang digunakan berbentuk Nonequivalent Control Grup Design. Sampel yang diteliti adalah peserta didik kelas IVA sebagai kelas eksperimen yang berjumlah 25 orang peserta didik dan kelas IVB sebagai kelas kontrol yang berjumlah 25 peserta. Teknik analisis pada penelitian ini adalah Uji beda dua rata-rata dengan Uji- $t$. Berdasarkan hasil perhitungan uji- $t$ diperoleh $t_{\text {hitung }}$ sebesar 4,5814 dan $t_{\text {tabel }} 2,0106$. Dengan demikian memenuhi kriteria pengujian $t_{\text {hitung }}>t_{\text {tabel }}$ pada taraf signifikan 5\%. Kesimpulannya terdapat perbedaan kemampuan berpikir kritis peserta didik dengan penerapan model inkuiri sosial peserta didik kelas IV Sekolah dasar pada mata pelajaran IPS, pada materi: (1) kegiatan ekonomi produksi, distribusi dan konsumsi; (2) jenis-jenis pekerjaan yang berhubungan dengan corak kehidupan masyarakat sekitar; dan (3) jenis-jenis pekerjaan menghasilkan barang dan jasa.
\end{abstract}

Kata kunci: keterampilan berpikir kritis, model inkuiri sosial.

\section{Identitas Artikel:}

Astuti, D. W. (2020). Penerapn Model Inkuiri Sosial terhadap Keterampilan Berpikir Kritis Mata Pelajaran IPS di Sekolah Dasar. Jurnal Ilmu Pendidikan (JIP) STKIP Kusuma Negara, 12(1), $35-42$.

\section{PENDAHULUAN}

Negara Indonesia adalah Negara yang memberikan masyarakatnya kebebasan untuk berbicara, mengemukakan pendapat dan mendapatkan serta menyebarkan berbagai informasi. Negara Indonesia telah memasuki abad ke-21 di mana seseorang dapat mendapatkan berbagai informasi dengan cepat dari berbagai sumber yang belum diketahui kebenarannya. Zaman telah memasuki Era globalisasi (Rizqi, 2020), tidak ada lagi batasan antar negara (Abduh \& Taniredja, 2017). Sekarang ini dunia seperti tidak ada batasan dan perkembangan teknologi, informasi dan komunikasi yang signifikan. Kondisi tersebut dapat menimbulkan kekhawatiran jika tidak pandai untuk mengelola informasi yang diterima, maka akan berdampak pada kebingungan, tidak tahuan informasi yang dapat dipercaya dan informasi yang tidak dapat dipercaya, mudah untuk terprovokasi dan diadu domba. Kemampuan berpikir kritis dapat menjadikan pelindung diri, dari berbagai informasi berita bohong dan dasar untuk mengambil sebuah keputusan. Peningkatan kualitas dan sumberdaya manusia sangat penting untuk menghadapi perkembangan teknologi dan pengetahuan (Hendracipta, Nurhakim \& Agustini, 2017). Untuk meningkatkan kualitas SDM dapat dilakukan melalui bidang 
pendidikan. Di dalam sebuah bidang pendidikan terdapat sebuah proses pembelajaran yang dapat membentuk dan mengoptimalkan kemampuan berpikir kritis peserta didik (Astuti, Suara \& Abadi, 2016).

Berpikir kritis adalah suatu cara berpikir tentang mengenai masalah yang dipaparkan atau konsep yang diberikan dalam bentuk ide atau gagasan (Susanto, 2014). Berpikir kritis dilakukan secara mendalam menyaring berbagai informasi yang didapatkan dan mencari kebenaran mengenai informasi yang di dapatkan, berpikir kritis dapat dikatakan berpikir secara logis berdasarkan fakta-fakta yang sesungguhnya. Melalui keterampilan berpikir kritis, peserta didik akan diajak untuk menganalisis kebenaran informasi yang didapatkan dari berbagai sumber dan membuat suatu keputusan (Nurlaela, 2017). Mengembangkan keterampilan berpikir kritis dapat dilakukan melalui pembelajaran Ilmu Pengetahuan Sosial.

Ilmu Pengetahuan Sosial (IPS) merupakan ilmu pengetahuan yang harus dikaji dan dianalisis berdasarkan fakta dan data yang ditemukan dari berbagai sumber, oleh karena itu IPS sangat penting untuk dipelajari, khususnya pada anak sekolah dasar (Susanto, 2014). Dalam pembelajaran IPS peserta didik akan mengaitkan materi yang dipelajari dengan fakta yang ada di dalam kehidupan nyata di sekitar kehidupan peserta didik, sehingga lebih mudah menarik kesimpulan dari materi yang diajarkan oleh guru. Dapat diartikan dengan pembelajaran IPS peserta didik akan diajak untuk berpikir kritis untuk menyikapi masalah atau isu-isu sosial yang ada disekitarnya (Sukardi, 2015).

Tetapi kenyataan yang terjadi di lapangan berdasarkan hasil observasi di kelas IV SD Negeri Pakulonan 01 Kota Tangerang Selatan. Model pembelajaran yang digunakan dalam pembelajaran IPS masih tradisional belum sesuai dengan perkembangan zaman yang semakin maju dan lingkungan peserta didik berada. Pembelajaran berlangsung secara konvensional, dengan pembelajaran seperti itu tentu tidak akan membuat kelas menjadi menyenangkan. Peserta didik belum di ikut sertakan secara aktif oleh guru belum di dalam kegiatan belajar mengajar (Antini, Negara \& Sujana, 2014). Pembelajaran yang berlangsung lebih banyak menuntut kekuatan ingatan dan hafalan peserta didik, contohnya pembelajaran materi proklamasi peserta didik akan menghafal kejadian-kejadian pada proses perumusan proklamasi serta tanggal dan tokoh yang berjasa tanpa menstimulus wawasan berpikir dan penyelesaian masalah-masalah. Belajar melalui cara menghafal akan membuat peserta didik ketergantungan dengan guru yang menjadi sumber informasi (Nursiti, 2013), menjadikan peserta didik tidak mempunyai keinginan untuk berpikir lebih mendalam karena informasi sudah disediakan.

Kemampuan peserta didik dalam menjawab soal berpikir kritis masih rendah terbukti dari hasil tes pra-penelitian yang dilakukan, hasil tes menunjukan hampir seluruh peserta didik mendapatkan nilai rendah dan guru dalam membuat soal evaluasi dan memberikan pertanyaan yang tidak memicu siswa untuk berpikir secara kritis. Guru memberikan pertanyaan kepada peserta didik yang jawabannya sudah tetera di dalam buku, menjadikan peserta didik hanya memindahkan jawaban saja tidak dipancing untuk peserta didik berpikir secara kritis

Untuk mengatasi permasalahan di atas perlu adannya suatu upaya pembelajaran yang dapat mengoptimalkan dan melatih peserta didik untuk berpikir secara kritis. Pendekatan pembelajaran yang dapat mengoptimalkan kemampuan berpikir kritis, salah satunya dengan menerapkan pendekatan pembelajaran yang aktivitas belajarnya berpusat kepada peserta didik, 
pembelajaran yang mampu membuat peserta didik yang aktif, mandiri dan bertanggung jawab sepenuhnya selama pembelajaran (Ariani, 2017). Salah satu model yang dapat digunakan dalam pembelajaran IPS adalah model inkuiri sosial. Model inkuiri sosial merupakan model pembelajaran yang relative baru dalam studi social, yang diadopsi dari model pembelajaran inkuiri yang biasanya diterapkan pada ilmu-ilmu sains. Model ini hasil pemikiran Hilda Taba dan T Richard Suchman, yang kemudian dikembangkan lebih jauh oleh Byron Massialas dan Benyamin Cox (Ritiauw \& Salamor, 2016).

Melalui model pembelajaran inkuiri sosial peserta didik dilatih untuk berpikir secara kritis, terutama dalam mempelajari pelajaran IPS, yang salah satunya menuntut peserta didik untuk kritis terhadap sumber dalam mengungkapkan fakta yang benar (Susanto, 2014)

Model pembelajaran inkuiri sosial merupakan model pembelajaran yang mengikutsertakan secara aktif peserta didik untuk mencari atau menyelidiki suatu benda atau suatu masalah secara kritis, masuk akal, sistematis dan analitis melalui berbagai macam sumber, sehingga mereka dapat menemukan sendiri penyelesaian dari suatu masalah (Wariyanti, Rusijono \& Nasution, 2019). Pembelajaran IPS dengan menggunakan model inkuiri sosial dapat melatih peserta didik untuk mengingkatkan keterampilan berpikir kritis karena pembelajaran inkuiri dapat membuat peserta didik berpikir secara kritis terhadap informasi yang di dapatkan dalam mengungkapkan fakta yang sebenarnya berdasarkan bukti yang dilihat, didengar dan dibaca. Model pembelajaran ini, peserta didik dapat memecahkan masalah-masalah sosial terutama melalui penyelidikan yang sistematis dan berpikir logis (Hendarwati, 2013). Peserta didik dapat menemukan sendiri konsep-konsep masalah sosial dan bagaimana cara untuk memecahkannya serta solusi yang tepat untuk permasalahan tersebut. Masalah-masalah yang ada di dalam pembelajaran model inkuiri sosial adalah masalah-masalah sosial yang berada di sekitar kehidupan peserta didik.

Langkah-langkah pembelajaran dalam model inkuiri sosial sebagai berikut: (1) tahap pertama (orientasi) berisi kegiatan menetapkan masalah sebagai pokok bahasan yang akan dirumuskan dalam bentuk pertanyaan; (2) tahap kedua (hipotesis), membuat jawaban sementara dari wawasan yang telah dimiliki sebelumnya; (3) tahap ketiga (definisi), menjabarkan hipotesis; (4) tahap keempat (eksploratif), berupa menguji hipotesis dengan menggunakan logika; (5) tahap kelima (pembuktian), mengumpulkan fakta-fakta dan data yang dibutuhkan; (6) tahap keenam (generalisasi), yakni membuat kesimpulan dari informasi yang telah didapatkan sebagai pemecahan atau jawaban terhadap permasalahan yang dapat diterima kebenarannya (Ritiauw \& Salamor, 2016; Salam, 2017).

Model pembelajaran inkuiri sosial memberikan banyak keuntungan peserta didik tidak lagi belajar dengan cara menghafal dalam pembelajaran IPS dan tidak lagi menjadikan guru sebagai sumber belajar, model pembelajaran inkuiri termasuk ke dalam pembelajaran yang menghasilkan karya berbasis pemecahan masalah, peserta didik diberikan proyek yang berdasarkan pada topik pembelajaran dan permasalahan yang menuntut peserta didik untuk mencari dan mengola informasi, membuat generalisasi, memecahkan permasalahan, dan memberikan pengalaman baru dalam belajar, peserta didik dapat memecahkan masalah-masalah sosial, terutama melalui penyelidikan yang sistematis dan berpikir logis. Peserta didik dapat menemukan dengan sendirinnya konsep-konsep 
masalah sosial dan bagaimana cara untuk memecahkannya serta solusi yang tepat untuk permasalahan tersebut dan memberikan latihan kepada peserta didik untuk berpikir secara kritis serta memberikan pengalaman belajar kepada peserta didik.

Berdasarkan permasalahan dan hasil obeservasi penulis tertarik untuk mengadakan penelitian dengan judul "penerapan model inkuiri sosial terhadap kemampuan berpikir kritis peserta didik pada mata pelajaran IPS di Sekolah Dasar". Perumusan masalah dari penelitian ini adalah "adakah perbedaan kemampuan berpikir kritis peserta didik dengan adanya penerapan model inkuiri sosial pada mata pelajaran IPS kelas IV Sekolah dasar?“. Dan tujuan penelitian ini adalah untuk mengetahui adakah perbedaan kemampuan berpikir kritis peserta didik dengan adanya penerapan model inkuiri sosial pada mata pelajaran IPS kelas IV Sekolah dasar.

\section{METODE PENELITIAN}

Metode penelitian ini adalah kuasi eksperimen (quasi experimental design). Dengan desain penelitian kuasi eksperimen nonequivalent control grup design. Desain penelitian nonequivalent control grup design dalam Sugiyono (2014) dapat dilihat sebagai berikut.

\begin{tabular}{|c|}
\hline $\mathrm{O}_{1} \mathrm{X} \mathrm{O}_{2}$ \\
$\mathrm{O}_{3}-\mathrm{O}_{4}$ \\
\hline--- \\
\hline
\end{tabular}

Keterangan:

O1 : Tes awal sebelum perlakuan diberikan pada kelompok kelas eksperimen.

O2 : Tes akhir setelah perlakuan diberikan pada kelompok kelas eksperimen.

O3 : Tes awal sebelum perlakuan diberikan pada kelompok kelas kontrol.

O4 : Tes akhir setelah perlakuan diberikan pada kelompok kelas kontrol.

$\mathrm{X}$ : Perlakuan dengan menggunakan model pembelajaran Inkuiri Sosial.

- $\quad$ : Perlakuan dengan menggunakan model pembelajaran konvensional.

----- : Garis ini dimaksudkan kelompok tidak dilakukan secara acak, namun menggunakan kelas yang sudah ada.

Penelitian dilaksanakan di SDN Pakulonan 01 Kota Tangerang Selatan pada semester genap tahun ajaran 2019/2020. Populasi pada penelitian ini adalah seluruh peserta didik kelas IV yang berjumlah 50 orang dan sampel penelitian ini adalah peserta didik kelas IVA sebagai kelas Eksperimen yang berjumlah 25 orang peserta didik diberikan perlakukan menggunakan model inkuiri sosial dan kelas IVB sebagai kelas kontrol yang berjumlah 25 peserta didik menggunakan pembelajaran konvensional. Teknik pengampilan sampel menggunakan teknik nonprobability sampling.

Instrumen penelitian ini adalah tes dalam bentuk uraian yang sesuai dengan indikator berpikir kritis. Diantaranya: (1) memberikan penjelasan sederhana, (2) membangun keterampilan dasar, (3) menyimpulkan, (4) memberikan penjelasan lanjut, (5) mengatur strategi dan taktik. Sebelumnya tes telah diuji validitas dan reabilitas, serta dianalisis daya pembeda dan indeks kesukaran soal. Sedangkan 
teknik analisis data menggunakan teknis analisis statistik deskriptif, pengujian prasyarat uji normalitas dan uji homogenitas kemudian uji hipotesis penelitian.

\section{HASIL DAN PEMBAHASAN}

Hasil penelitian ini menemukan bahwa terdapat perbedaan kemampuan berpikir kritis setelah penerapan model inkuiri sosial pada mata pelajaran IPS di Kelas IV Sekolah Dasar. Hal ini dibuktikan dengan analisis tes kemampuan berpikir kritis pada pretes kelompok ekperimen dan kontrol dan postes kelompok ekperimen dan kontrol. Tes ini sebanyak 8 butir dan dibuat sesuai dengan indikator berpikir kritis. Sebelum dijadikan alat pengumpul data, intrumen tes di uji validasi, realibilitas, daya pembeda dan indeks kesukaran kepada non sampel yaitu peserta didik kelas VA. Dari 8 butir, seluruhnya valid dan reliabel. Setelah itu dilakukan analisis daya pembeda dan indeks kesukaran. Dari 8 butir 1 butir soal dengan tingkat kesukaran "mudah", 1 butir soal "sukar" dan 6 butir soal "sedang". Daya pembeda instrumen tes penelitian dari 8 soal diperoleh 4 butir soal dengan daya pembeda "cukup", 3 butir soal dengan daya pembeda "baik" dan 1 butir soal dengan daya pembeda yang "sangat baik". Data hasil penelitian postes kelompok ekperimen dan kontrol dapat dilihat pada Tabel berikut ini.

\begin{tabular}{lcc}
\multicolumn{3}{l}{ Tabel 1. Statistik Deskriptif Data Postes Kelompok Eksperimen Dan Kontrol } \\
\hline Data & Eksperimen & Kontrol \\
\hline Banyak peserta didik & 25 & 25 \\
Nilai tertinggi & 53.1 & 46.9 \\
Nilai terendah & 90.6 & 75 \\
Mean & 74.75 & 60.5 \\
Median & 81.3 & 62.5 \\
Modus & 81.3 & 62.5 \\
Standar deviasi & 12.267 & 9.015 \\
Varians & 150.5 & 81.3 \\
\hline
\end{tabular}

Dari Tabel di atas dapat dilihat bahwa banyak peserta didik pada kelas ekperimen dan kontrol berjumlah sama yaitu 25. Hasil postes pada kelas eksperimen memperoleh nilai rata-rata sebesar 74,75 dengan jumlah peserta didik sebanyak 25. Nilai terendah 53,1 dan terbesar 90,6. Dengan modus dan median sebesar 81,3 Sedangkan pada kelas kontrol memperoleh nilai rata-rata sebesar 60,5 dengan jumlah siswa sebanyak 25. Nilai terendah 46,9 dan terbesar 75 dengan median dan modus sebesar 62,5. Hal ini mencerminkan bahwa adanya perbedaan kemampuan berpikir kritis peserta didik dengan diterapkannya model inkuiri sosial.

Uji Normalitas postes kelompok kontrol dan ekperimen dilakukan dengan cara mebandingkan hasil uji Liliefors dengan nilai kritis uji Liliefors. Didasarkan atas analisa data, data uji normalitas dapat dilihat pada Tabel 2.

Tabel 2. Hasil Uji Normalitas

\begin{tabular}{lccc}
\hline Data & $L_{\text {hitung }}$ & $L_{\text {tabel }}$ & Simpulan \\
\hline Kontrol & 0.159 & \multirow{2}{*}{0.173} & \multirow{2}{*}{ Normal } \\
Eksperimen & 0.121 & & \\
\hline
\end{tabular}


Berdasarkan hasil perhitungan, sebagaimana tercantum pada Tabel 2 di atas, diperoleh berdasarkan data postes dari kelas kontrol dan eksperimen, didapatkan nilai $L_{\text {hitung }}$ sebesar 0,159 untuk kelas kontrol dan $L_{\text {hitung }}$ sebesar 0,121 untuk kelas ekperimen, sedangkan nilai kritis $L$ untuk sampel $(n)$ sebanyak 50 dan $\alpha=0,05$ adalah 0,173 . Karena $0,159<0,173$ dan $0,121<0,173$, maka dapat dikatakan bahwa hasil uji normalitas pada data postest berdistrubusi normal.

Hasil perhitungan uji homogenitas postes dapat dilihat pada Tabel 5 di bawah ini.

Tabel 3. Hasil Uji Homogenitas

\begin{tabular}{lcccccc}
\hline Data & Varians & $F_{\text {hitung }}$ & $F_{\text {tabel }}$ & $d b_{\text {pembilang }}$ & $d b_{\text {penyebut }}$ & Simpulan \\
\hline Kontrol & 81,3 & 1,84 & 1,98 & 24 & 24 & Homogen \\
Eksperimen & 150,5 & & & & & \\
\hline
\end{tabular}

Berdasarkan Tabel 3 di atas, diperoleh dari data postes maka dapat dilihat pada Tabel didapatkan nilai $F_{\text {hitung }}$ adalah 1,84 ; sedangkan $F_{\text {tabel }}$ adalah 1,98 dengan taraf signifikan $\alpha=0,05 ; d k_{\text {pembilang }}=25-1$; dan $d k_{\text {penyebut }}=25-1$. Karena $F_{\text {hitung }}<$ $F_{\text {tabel }}$ dengan nilai sebagai berikut: $1,84<1,98$. Dapat dikatakan bahwa hasil uji homegenitas dari postes kelompok kontrol dan ekperimen adalah homogen. Karena analisis data terpenuhi, maka selanjutnya dilakukan uji analisis data penelitian uji beda dua rata-rata dengan uji-t. Hasil perhitungan uji-t dapat dilihat pada Tabel 4 Berikut.

Tabel 4. Hasil Uji Hipotesis

\begin{tabular}{lcccl}
\hline Kelas & Rata-rata Postes & $t_{\text {hitung }}$ & $t_{\text {tabel }}$ & Simpulan \\
\hline Eksperimen & 74,75 & \multirow{2}{*}{4,581} & \multirow{2}{*}{2,011} & Terdapat Perbedaan \\
Kontrol & 60,5 & & & Rata-rata \\
\hline
\end{tabular}

Pada Tabel 4 di atas, menunjukan $t_{\text {hitung }}$ sebesar 4,581 dan $t_{\text {tabel }}$ sebesar 2,011. Dengan demikian memenuhi kriteria pengujian $t_{\text {hitung }}>t_{\text {tabel }}$, maka hipotesis diterima pada taraf kepercayaan $95 \%$ dan nilai derajat kebebasan sebesar 48, yang berarti ini menunjukan bahwa terdapat perbedaan kemampuan berpikir kritis peserta didik dengan penerapan model inkuiri sosial. Hal ini berarti, bahwa pemberian perlakukan di kelas eksperimen dengan menerapkan model inkuiri sosial dapat memberikan perbedaan kemampuan berpikir kritis peserta didik pada mata pelajaran IPS materi: (1) kegiatan ekonomi produksi, distribusi dan konsumsi; (2) jenis-jenis pekerjaan yang berhubungan dengan corak kehidupan masyarakat sekitar; dan (3) jenis-jenis pekerjaan menghasilkan barang dan jasa.

Berdasarkan hasil postes yang didapatkan dua kelompok mengalami perbedaan nilai rata-rata pada kelompok kelas kontrol peserta didik mendaptkan nilai ratarata 60,5 . Sedangkan untuk kelas ekperimen memperoleh hasil rata-rata sebesar 74,75. Uji hipotesis dengan menggunakan Uji beda dua rata-rata dengan Uji-T pada taraf signifikan 95\%. Dari hasil perhitungan postes yang di peroleh $t_{\text {hitung }}$ sebesar 4,581 dan $t_{\text {tabel }} 2,011$. Dengan demikian memenuhi kriteria pengujian $t_{\text {hitung }}$ $>t_{\text {tabel }}$, maka hipotesis diterima pada taraf kepercayaan $95 \%$ dan nilai derajat kebebasan sebesar 48. Hal ini menunjukan bahwa terdapat perbedaan kemampuan 
berpikir kritis dengan penerapan model inkuiri sosial pada mata pelajaran IPS di kelas IV Sekolah Dasar.

Hasil penelitian ini juga sejalan dengan hasil penelitian sebelumnya oleh Suprihatin (2017), Rodiyana (2015), Lilasari (2019) yang menemukan kemampuan berpikir kritis peserta didik dapat meningkat dari kategori cukup menjadi kritis memalui pembelajaran inkuiri sosial pada mata pelajaran IPS di SD.

\section{KESIMPULAN}

Berdasarkan hasil penelitian dan pembahasan mengenai penerapan model inkuiri sosial terhadap keterampilan berpikir kritis peserta didik di kelas IV SDN Pakulonan 01 Kota Tangerang Selatan, penulis menarik kesimpulan bahwa penerapan model inkuiri sosial dapat memberikan perbedaan kemampuan berpikir kritis peserta didik di kelas IV mata pelajaran IPS pada materi 1) kegiatan ekonomi produksi, distribusi dan konsumsi (2) jenis-jenis pekerjaan yang berhubungan dengan corak kehidupan masyarakat sekitar (3) jenis-jenis pekerjaan menghasilkan barang dan jasa.

Saran untuk guru yaitu Guru dapat menerapkan model inkuiri sosial dalam pembelajaran IPS untuk mengembangkan kemampuan berpikir kritis.. Penerapan model inkuiri dapat membuat peserta didik berlatih untuk berpikir secara kritis memalui serangkai tahapan pembelajaran dibandingkan dengan menggunakan model konvensional dan guru dapat membuat tes yang dapat mengembangkan kemampuan peserta didik untuk berpikir secara kritis.

\section{REFERENSI}

Abduh, M., \& Taniredja, T. (2017). Developing Values of Pancasila's Second Principle for Sixth Grader Students. Scholaria: Jurnal Pendidikan Dan Kebudayaan, 7(2), 165-178.

Antini, N. K. A., Negara, I. G. A. O., Ke, S. P. M., \& Sujana, I. W. (2014). Model Pembelajaran Inkuiri Terbimbing Berbantuan Media Audio-Visual Berpengaruh Terhadap Hasil Belajar IPS Siswa Kelas V SD Gugus Letda Kajeng. MIMBAR PGSD Undiksha, 2(1), 1-10.

Ariani, D. N. (2017). Pengaruh Model Pembelajaran Bebasis Masalah Dengan Pendekatan Saintifik Terhadap Kemampuan Berpikir Kritis Matematis Mahasiswa/I PGMI. Muallimuna: Jurnal Madrasah Ibtidaiyah, 3(2), 108115.

Astuti, H. D., Suara, I. M., \& Abadi, I. B. G. S. (2016). Penerapan model problem based learning untuk meningkatkan penguasaan kompetensi pengetahuan ips dan kemampuan berpikir kritis tema sejarah peradaban indonesia siswa kelas v sdn 1 sumerta tahun ajaran 2015/2016. MIMBAR PGSD Undiksha, 4(1), 1-10.

Hendarwati, E. (2013). Pengaruh pemanfaatan lingkungan sebagai sumber belajar melalui metode inkuiri terhadap hasil belajar siswa SDN I Sribit Delanggu pada pelajaran IPS. Pedagogia: Jurnal Pendidikan, 2(1), 59-70.

Hendracipta, N., Nurhakim, L., \& Agustini, S. M. (2017). Perbedaan Kemampuan Berpikir Kritis Siswa Melalui Penerapan Model Inkuiri Terbimbing Di Sekolah Dasar .Jurnal Pendidikan Guru Sekolah Dasar , 3(2), 215-227. 
Lilasari, Q. I. E. (2019). Pengembangan Perangkat Pembelajaran Inkuiri untuk Meningkatkan Kemampuan Berpikir Kritis pada Mata Pelajaran IPS Materi Masalah Sosial Kelas IV Sekolah Dasar. Jurnal Review Pendidikan Dasar: Jurnal Kajian Pendidikan dan Hasil Penelitian, 5(2), 1009-1018.

Nurlaela, L. (2017). Pengaruh Media Pembelajaran Dan Motivasi Belajar Terhadap Kemampuan Berpikir Kritis Siswa. Jurnal Ilmiah Pendidikan Guru Sekolah Dasar, 1(2), 180,187.

Nursiti, N. (2013). Keterampilan berpikir kritis (critical thinking skill) dalam pembelajaran ilmu pengetahuan sosial. Widyaiswara LPMP Jawa Barat, 1(1), $1-10$.

Ritiauw, S. P., \& Salamor, L. (2016). Mengembangkan Keterampilan Berpikir Kritis Siswa Sekolah Dasar Melalui Implementasi Model Pembelajaran Sosial Inkuiri. Jurnal Pedagogika dan Dinamika Pendidikan , 4(1), 43-56.

Rizqi, Y. F. (2020). Implementasi Nilai Karakter Pada Pembelajaran IPS Untuk Mengantisipasi Isu Global Di Sekolah Menengah Pertama. Historika, 23(1), 41-58.

Rodiyana, R. (2015). Pengaruh Penerapan Strategi Pembelajaran Inkuiri Terhadap Kemampuan Berpikir Kritis dan Kreatif Siswa SD. Jurnal Cakrawala Pendas, 1(1), 34-43.

Salam, R. (2017). Model Pembelajaran Inkuiri Sosial dalam Pembelajaran IPS. Harmony, 2(1), 7-12.

Sugiyono. (2014). Metode Penelitian Pendidikan Pendekatan Kuantitatif, Kualitatif dan R\&D. Bandung: Alfabeta

Sukardi, T. (2015). Pengembangan Strategi Konstruktivistik dalam Pembelajaran IPS untuk Meningkatkan Kepekaan Sosial Mahasiswa. Sosiohumanika, 8(1), 55-66.

Suprihatin. (2015). Peningkatan Kemampuan Berpikir Kritis Dan Interaksi Sosial Siswa Melalui Model Pembelajaran Inkuiri Sosial Pada Mata Pelajaran IPS di SD (Publikasi No. 31072) [Magister Tesis, Universitas Pendidikan Indonesia]. Perpustakaan Universitas Pendidikan Indonesia.

Susanto, A. (2014). Pengembangan Pembelajaran IPS di Sekolah Dasar. Jakarta : Prenadamedia Group.

Wariyanti, A., Rusijono., \& Nasution. (2019). Pengaruh Model Pembelajaran Inkuiri terhadap Kemampuan Berpikir Kritis dan Hasil Belajar Siswa Kelas IV SD pada Subtema Keindahan Alam Negeriku. Jurnal Review Pendidikan Dasar: Jurnal Kajian Pendidikan dan Hasil Penelitian, 5(2), 1019-1024. 